\title{
ANALISIS KEMAMPUAN KOMUNIKASI MATEMATIS DAN MINAT BELAJAR SISWA SMP PADA MATERI SEGITIGA DAN SEGIEMPAT
}

\author{
Nuron $^{1}$, Dede Sopandi ${ }^{2}$, Veny Triyana Andika Sari ${ }^{3}$ \\ 1,2,3 Institut Keguruan dan Ilmu Pendidikan Siliwangi, J1. Terusan Jenderal Sudirman, Cimahi \\ 12akangnuron51@gmail.com, 2azzamsopandi@gmail.com, ${ }^{3}$ venytriyana@ymail.com
}

\begin{abstract}
The purpose of this study is to analyze the ability of mathematical communication and student learning interest and describe it especially on triangle and quadrilateral material on the students of class VII PGRI 168 Cikalongwetan Junior High School. The research method used is descriptive qualitative. The subjects studied are class VII SMP PGRI 168 Cikalongwetan consisting of 6 people. The instrument used in the form of a written test that contains 5 items about mathematical communication and 25 students questionnaire scale student interest. The results were tested statistically using SPSS IDM sofwere version 21 to find normality and correlation using product moment person. Data validity is done by triangulation technique and source triangulation. The results of the research show that there is a relationship that interplay between the ability of mathematical communication and student learning interest.
\end{abstract}

Keywords: Mathematical Communication, Interest In Learning

\begin{abstract}
Abstrak
Tujuan penelitian ini untuk menganalisis kemampuan komunikasi matematis dan minat belajar siswa serta mendeskripsikannya terutama pada materi segitiga dan segiempat pada siswa kelas VII SMP PGRI 168 Cikalongwetan. Metode penelitian yang digunakan adalah deskriptif kualitatif. Adapun subjek yang diteliti adalah kelas VII SMP PGRI 168 Cikalongwetan yang terdiri dari 6 orang. Instrumen yang digunakan berupa tes tertulis yang memuat 5 butir soal komunikasi matematis dan 25 skala angket minat belajar siswa. Hasil penelitian diuji statistik menggunakan sofwere IDM SPSS Versi 21 untuk mencari normalitas dan korelasi menggunakan product momen person. Keabsahan data dilakukan dengan triangulasi teknik dan triangulasi sumber. Hasil penelitian yang dilakukan menunjukan terdapatnya hubungan yang saling mempengaruhi antara kemampuan komunikasi matematis dan minat belajar siswa.
\end{abstract}

Kata Kunci: Komunikasi Matematis, Minat Belajar

How to cite: Nuron, Sopandi, D., \&Sari, V. T. A. (2018). Analisis Kemampuan Komunikasi Matematis dan Minat Belajar Siswa SMP pada Materi Segitiga dan Segiempat. JPMI-Jurnal Pembelajaran Matematika Inovatif, 1 (4), 617-622.

\section{PENDAHULUAN}

Kemampuan komunikasi matematis diperlukan dalam pembelajaran matematika untuk mengorganisasi, mengonsolidasi dan mengeksplorasi ide-ide matematikanya (Elia, 2014; Hidayat, \& Sumarmo, 2013; Rahmi, Nadia, Hasibah, \& Hidayat, 2017; Zakiah, Saomi, Syara, Hidayat, \& Hendriana, 2018). Sesuai dengan ungkapan Baroody (Umar, 2012), bahwa "Pembelajaran harus dapat membantu siswa mengkomunikasikan ide matematika melalui lima aspek komunikasi yaitu representing, listening, reading, discussing dan writing". Setidaknya itulah hal penting dari komunikasi yang berfungsi sebagai media interaksi antara guru dengan siswa bahkan juga siswa dengan siswa. 
Membiasakan siswa memberikan pertanyaan dan pendapat dalam proses belajar mengajar akan membuat pelajaran itu semakin bermakna. menurut Huang dan Normandia (Siti, 2015), menyatakan "Komunikasi menjadi satu bagian penting dari matematika untuk membangun mathematical thinking". Hal tersebut menunjukan bahwa komunikasi menjadi alasan utama untuk mencapai sebuah peningkatan dalam belajar.

Matematika merupakan mata pelajaran yang kurang diminati oleh siswa, karena mereka beranggapan bahwa matematika itu sulit dan membosankan, sehingga diperlukan perkembangan dalam suatu pembelajaran untuk menambah minat belajar siswa, sejalan dengan Hendriana (2017) mengemukakan "Bahwa minat dapat mendorong berlangsungnya keikutsertaan dalam suatu kegiatan". Minat yang besar akan memberikan pengaruh dalam proses pembelajaran yang lebih baik karena adanya keinginan dan rasa sungguh-sungguh dalam belajar. Minat belajar juga memiliki peran yang penting dalam pembelajaran seperti yang dikemukakan Gie (Hendriana, 2017), yaitu: (a) minat melahirkan perhatian secara bersamaan, (b) minat membantu terciptanya konsentrasi, (c) minat membentengi diri dari berbagai gangguan, (d) minat mempermudah pelajaran untuk diingat, (e) minat mengurangi rasa bosan dalam belajar".

Berbagai alasan terlontar dari peserta didik untuk tidak belajar terutama pada materi segitiga dan segiempat yang di ajarkan pada kurikulum SMP kelas VII. Mereka mengganggap materi tersebut adalah materi pelajaran yang sulit karena terlalu banyak rumus dan hafalan yang harus diingat oleh siswa. Padalah dalam materi tersebut terkandung banyak hal yang berkaitan dalam kehidupan sehari-hari. untuk mengurangi kesulitan siswa dalam belajar pada materi tersebut perlulah inovasi pendidikan yang mengunakan IT. Penggunaan software matematika untuk pembelajaran, diharapkan dapat membantu dalam memahami dan menambah minat belajar siswa yang menganggap pelajaran matematika rumit, susah, dan membosankan (Kartika, 2014).

Berdasarkan paparan diatas, maka peneliti berniat untuk menganalisa hubungan antara komunikasi matematis dengan minat belajar, apakah terjadi terjadi keterkaitan atau tidak.

\section{METODE}

Penelitian ini termasuk kategori deskriptif kualitatif yang bertujuan untuk mendeskripsikan hubungan keterkaitan antara komunikasi matematis dengan minat belajar sesuai fakta yang terjadi pada saat penelitian dilapangan. Jawaban siswa melalui tes tertulis merupakan hasil dari penelitian sebagai bahan untuk mencari normalitas dan korelasi dengan menggunakan product momen person. Subjek penelitian ini dilakukan pada siswa kelas VII SMP PGRI 168 Cikalongwetan yang terdiri dari 6 orang. Instrumen yang digunakan berupa tes tertulis yang memuat 5 butir soal komunikasi matematis dan 25 skala angket minat belajar siswa..

\section{HASIL DAN PEMBAHASAN}

\section{Hasil}

Setelah dilakukan penelitian, peneliti melakukan uji instrumen soal uraian materi segitiga dan segi empat kepada peserta didik sebagai olahan untuk dilakukan uji normalitas dan korelasi. Data tersebut tertuang pada Tabel. 1 sebagai berikut: 
Tabel 1. Data Hasil Uji Coba Instrumen Soal Uraian

\begin{tabular}{llllllll} 
Kode & \multicolumn{9}{l}{ Skor Untuk Tiap Butir Soal } & & $\begin{array}{l}\text { Skor } \\
\text { Siswa }\end{array}$ & $\mathbf{X}$ 1 & $\mathbf{X 2}$ & $\mathbf{X 3}$ & $\mathbf{X} 4$ & $\mathbf{X 5}$ & Total & Rata-rata \\
\hline S-1 & 1 & 1 & 1 & 1 & 1 & 5 & 1,00 \\
S-2 & 4 & 2 & 1 & 1 & 1 & 9 & 1,80 \\
S-3 & 3 & 1 & 4 & 2 & 1 & 11 & 2,20 \\
S-4 & 3 & 2 & 4 & 2 & 3 & 14 & 2,80 \\
S-5 & 1 & 1 & 1 & 2 & 1 & 6 & 1,20 \\
S-6 & 1 & 1 & 1 & 2 & 0 & 5 & 1,00 \\
Jumlah & 13 & 8 & 12 & 10 & 7 & 50 & 10,00 \\
\hline Rata-Rata & 2,17 & 1,33 & 2,00 & 1,67 & 1,17 & 8,33 & 1,67 \\
\hline
\end{tabular}

Berdasarkan Tabel 1. diperoleh dimana dari 6 siswa hanya satu yang mencapai rata-rata 2,80, artinya masih lemahnya kemampuan komunikasi matematis yang dimiliki siswa.

Tabel 2. Data Hasil Angket

\begin{tabular}{llllll}
\multirow{2}{*}{ kode siswa } & \multicolumn{5}{l}{ skor angket per indikator } \\
\cline { 2 - 6 } & $X 1$ & $X 2$ & $X 3$ & $X 4$ & $X 5$ \\
\hline S1 & 14 & 7 & 11 & 11 & 6 \\
S2 & 7 & 12 & 14 & 12 & 4 \\
S3 & 10 & 10 & 11 & 12 & 9 \\
S4 & 13 & 12 & 14 & 15 & 5 \\
S5 & 9 & 13 & 15 & 5 & 6 \\
Jumlah & 61 & 68 & 81 & 67 & 38 \\
\hline Rata-rata & 10,17 & 11,33 & 13,50 & 11,17 & 6,33 \\
\hline
\end{tabular}

Tabel 2. diatas menjelaskan data angket dari siswa yang diteliti per indikator, terlihat untuk indikator yang masih rendah terdapat di indikator 5 dengan rata-rata sebesar 6,33.

Tabel 3. Hasil Uji Normalitas Kemampuan Komunikasi dengan Minat Belajar

\begin{tabular}{llllc}
\multirow{2}{*}{ afektif } & \multicolumn{3}{c}{ Shapiro-Wilk } \\
\cline { 2 - 4 } kemampuan_matematis & Statistic & df & Sig. \\
& $\begin{array}{l}\text { komuniasi_matema } 0,889 \\
\text { tis }\end{array}$ & 6 & 0,312 \\
\cline { 2 - 5 } & minat_belajar & 0,828 & 6 & 0,103 \\
\hline
\end{tabular}

Dari Tabel 3. Didapatkan nilai signifikan kemampuan komunikasi sebesar 0,312 $\geq 0,05$ dan minat belajar sebesar $0,103 \geq 0,05$, artinya kedua variabel tersebut berdistribusi normal.

Setelah diketahui data tersebut berdistribusi normal maka akan dilakukan analisis korelasi untuk mengetahui sejauh mana hubungan antara kemampuan komunikasi matematis dan minat belajar siswa. 
Tabel 4. Hasil Korelasi Kemampuan Komunikasi dengan Minat Belajar

\begin{tabular}{llll}
\hline & & $\begin{array}{l}\text { Kemampuan } \\
\text { komunikasi }\end{array}$ & Minat belajar \\
\hline $\begin{array}{l}\text { Kemampuan } \\
\text { komunikasi }\end{array}$ & $\begin{array}{l}\text { Pearson } \\
\text { correlations } \\
\text { sig (2-tailed) }\end{array}$ & 10 & 9,134 \\
& $\mathrm{~N}$ & 6 & 0.000 \\
\hline Minat belajar & $\begin{array}{l}\text { Pearson } \\
\text { correlations }\end{array}$ & 9,134 & 6 \\
& Sig(2-tailed) & 6 & 10 \\
& $\mathrm{~N}$ & & 6 \\
& & & \\
& &
\end{tabular}

Dari hasil output diatas dapat dilihat nilai signifikansi kemampuan komunikasi matematis dengan minat belajar siswa sebesar $0,000<0,05$, yang berarti kemampuan komunikasi mempunyai hubungan dengan minat belajar siswa dalam pembelajaran matematika SMP khususnya pada materi segitiga dan segiempat.

\section{Pembahasan}

Dari hasil uji coba instrumen yang terdapat pada Tabel 1. Materi segitiga dan segiempat pada tingkat SMP perlu ditingkatkan kembali. Pada dasarnya memang materi tersebut tidaklah mudah untuk disampaikan kepada peserta didik. Guru harus mencari inovasi kembali untuk memberikan penyampaian pembelajaran yang sesuai baik itu dengan alat peraga ataupun media pembelelajaran berbasis IT seperti diungkapkan Hamalik (Suryani, 2015) bahwa pemakaian media pengajaran dalam proses belajar mengajar dapat membangkitkan keinginan dan minat yang baru, membangkitkan motivasi dan rangsangan kegiatan belajar, dan bahkan membawa pengaruh-pengaruh psikologis terhadap siswa.

Pengujian statistik menunjukan bahwa komunikasi matematis erat kaitannya dengan minat belajar karena berdasarkan hasil uji korelasi menunjukan bahwa terjadinya pengaruh yang besar terhadap nilai siswa. Nilai kognitif yang diperoleh bisa meningkat apabila siswa mempunyai minar belajar yang tinggi. Peningkatan tersebut bisa tercapai apabila siswa menyukai mata pelajaran itu sendiri. Pembelajaran matematika yang humanis, tentu akan berakibat pada diri siswa untuk senang dan tertarik dalam belajar matematika (Hendriana, 2014).

\section{KESIMPULAN}

Setelah dilakukan pengujian data hasil penelitian hubungan keterkaitan antara komunikasi matematis dan minat belajar siswa dapat disimpulkan bahwa:

1. Kemampuan komunikasi matematis di jenjang sekolah menengah pertama khususnya pada materi segitiga dan segiempat belum menunjukan hasil yang baik yang artinya masih lemahnya kemampuan komunikasi matematis sehingga perlu di tingkatkan kembali.

2. Terdapatnya hubungan yang saling mempengaruhi antara kemampuan komunikasi matematis dan minat belajar siswa.

\section{UCAPAN TERIMA KASIH}

1. Kepala sekolah SMP PGRI 168 Cikalongwetan yang telah mengijinkan kami untuk melakukan penelitian.

2. Ibu Veny Triyana Andika Sari, M.Pd. yang telah membimbing kami untuk menyelesaikan 
jurnal ini.

3. Kedua orang tua kami beserta orang-orang terdekat yang telah memberikan dukungan dan semangat dalan menyelesaikan penelitian ini.

\section{DAFTAR PUSTAKA}

Elia, I. S. (2014) “Komunikasi dalam Pembelajaran Matematika," Prosiding Seminar Nasional Pendidikan Matematika, 1, hal. 152-156.

Hendriana, H. (2014) "Membangun Kepercayaan Diri Siswa Melalui Pembelajaran Matematika Humanis," Jurnal Pengajaran MIPA, 19(1), hal. 52-60. doi: http://dx.doi.org/10.18269/jpmipa.v19i1.424.

Hendriana, H. (2017) Hard Skills dan Soft Skills Matematik Siswa. Bandung: Refika Aditama.

Hidayat, W., \& Sumarmo, U. (2013). Kemampuan Komunikasi dan Berpikir Logis Matematika serta Kemandirian Belajar. dalam Jurnal Delta-fi, 2(1).

Kartika, H. (2014) "Pembelajaran Matematika Berbantuan Software Matlab sebagai Upaya Meningkatkan Kemampuan Komunikasi Matematis dan Minat Belajar Siswa SMA," Jurnal Pendidikan UNSIKA, 2(1), hal. 24-35.

Rahmi, S., Nadia, R., Hasibah, B., \& Hidayat, W. (2017). The Relation between Self-Efficacy toward Math with the Math Communication Competence. Infinity Journal, 6(2), 177 182.

Siti, M. S. R. (2015) "Pendekatan Brainstorming Round-Robin Untuk Meningkatkan Kemampuan Komunikasi Matematis Siswa SMP," Jurnal Ilmiah Program Studi Matematika STKIP Siliwangi Bandung, 4(2), hal. 190-196.

Suryani, N. (2015) “Pengembangan ICT dalam Pembelajaran,” (November), hal. 102-114.

Umar, W. (2012) "Membangun Kemampuan Komunikasi Matematis Dalam Pembelajaran Matematika," Infinity Journal, 1(1), hal. 1. doi: 10.22460/infinity.v1i1.2.

Zakiah, L., Saomi, A. S. N., Syara, R., Hidayat, W., \& Hendriana, H. (2018). THE EFFICIENCY OF USING EDUCATION VIDEOS ON THE LINEAR PROGRAM MATERIAL AS OBSERVED IN VOCATIONAL HIGH SCHOOL STUDENTS'MATHEMATICAL COMMUNICATION ABILITY. Journal Of Educational Experts (JEE), 1(1), 11-18. 
622 Nuron, Sopandi, \& Sari, Analisis Kemampuan Komunikasi Matematis dan Minat .... 